eridemia: its etiology, effects and treatment. CMA 2007; I76:III3-20.

2. Hsia SH, Connelly PW, Hegele RA. Successful outcome in severe pregnancy-associated hyperlipemia: a case report and literature review. Am Med Sci 1995;309:213-8.

DOI:Io.1503/cmaj.I070076

\section{Stepping down from CIHR}

I am writing to clarify my reasons for stepping down as President of the Canadian Institutes of Health Research (CIHR). Contrary to what Wayne Kondro wrote in the news article on my leaving, ${ }^{1}$ I am not "weary of serving as the scapegoat." On the contrary, I have enjoyed and appreciated the important discussions and debates that the CIHR vision and programs have prompted. Vigorous discussion is necessary for transformative change. The profound changes taking place in the style, speed and cost of health research, and in society more broadly, are prompting similar discussions in every country that wishes to be at the leading edge of health research and its translation into policy, products and clinical practice.

Contrary to what Mr. Kondro wrote, the internal changes in our structure were prompted by suggestions from the prestigious International Review Panel. The panel, in its highly positive review, suggested changes that "represent a natural progression in the growth of this new entity...." It also commented that "the capacity to fund research across all health related disciplines has clearly been enhanced and new strategic initiatives have strengthened multidisciplinary research and training. Together, these changes have all occurred in a remarkably short time frame, evidence of the commitment and success of the management team."

Finally, I am leaving because, after $7^{1 / 2}$ years as CIHR's first president, I have accomplished what I set out to do: establish a new national agency that funds research across all aspects of health and disease and that is strategic, committed to translating new knowl- edge into improved health of Canadians, focused on outcomes and based on peer-reviewed excellence in research. Furthermore, CIHR's unique structure of cross-Canada institutes is now well in place, with 13 highly talented and committed scientific directors, I3 Institute Advisory Boards and a strong senior management team here in Ottawa. Finally, I have always felt that it is not healthy to be the head of an organization such as CIHR for more than $7-8$ years: one tends increasingly to look backward, not forward.

As the International Review Panel noted, a great deal has been accomplished at CIHR over the past 7 years owing to the passion and commitment of all those who are on CIHR's staff or serve as volunteers on Governing Council, Institute Advisory Boards, Peer Review Committees and various ad hoc working groups and standing committees. The breadth and excellence of CIHR-funded research is something that all Canadians, particularly those of us actively involved in 
health research and health care, should take great pride in. This is a good time for someone else to take the reins of CIHR.

\section{Alan Bernstein PhD LLD (Hon) \\ President, Canadian Institutes of Health Research \\ Ottawa, Ont.}

Competing interests: None declared.

\section{REFERENCE}

I. Kondro W. Bernstein bails presidency. CMAJ 2007; I77:24I.

DOI:I0.1503/cmaj.1070103

\section{[CMAJ responds:]}

We thank Alan Bernstein for his clarification. CMAJ stands by Wayne Kondro's article.

Paul C. Hébert MD MHSc

Editor-in-Chief

Barbara Sibbald BJ

Deputy Editor, News and Humanities CMAJ

DOI:I0.1503/cmaj.071138

\section{Reed Elsevier's arms}

\section{business}

CMAJ should be applauded for its news article highlighting the conflict of interest in Reed Elsevier's roles as a medical publisher and an organizer of arms fairs. ${ }^{1}$ Following similar articles in other journals, ${ }^{2-4}$ petitions by academics, actions of major shareholders and protests by the Campaign Against Arms Trade and the Global Health Advocacy Project, Reed Elsevier announced on June I, 2007, that its subsidiary company Reed Exhibitions would "divest of all [its] defence shows" as they are "no longer compatible with Reed Elsevier's position as a leading publisher of scientific, medical, legal and business content." ${ }^{5}$ This marks a rethink from its previous position that "the company does not regard this as a conflict of interest." Although dubious arms exhibitions will no doubt continue to be held, the success of this particular campaign demonstrates the potential impact of the global medical community when it acts in concert.

\section{Edward J.L. Armstrong BSc \\ Medical student \\ Imperial College \\ London, UK}

Competing interests: Edward Armstrong is a member of the Global Health Advocacy Project.

\section{REFERENCES}

I. Sibbald B. The Lancet protests against its publisher's arms fair business. CMAJ 2007;176:1265.

2. The editors of The Lancet reply. Lancet 2007;334: 547-8.

3. Young C, Godlee F. Reed Elsevier's arms trade. BMJ 2007;334:547.

4. Armstrong E. Taking the lead against Reed Elsevier. JR Soc Med 2007;100:256.

5. Important announcement: divestment of defence exhibitions [press release]. London (UK): Reed Elsevier; 2007 June I. Available: www.reed-elsevier.com |index.cfm?articleid=2084 (accessed 2007 Aug 7).

DOI:I0.1503/cmaj.1070082

\section{Open Medicine and open}

\section{access}

Although the endorsement by $C M A{ }^{\prime}$ 's editors of open-access medical publishing is welcome, ${ }^{1}$ we would like to point out that there is an important distinction between open- and free-access publication. The editors of Open Medicine have not only adopted the principle of free access, that is, making content fully available online, but we also endorse the definition of open-access publication set out in the Bethesda Statement on Open Access Publishing. ${ }^{2}$ This definition stipulates that the copyright holder grants to all users a free, irrevocable, worldwide and perpetual right of access to, and a licence to copy, use, distribute, transmit and display the work publicly and to make and distribute works derived from the original work, in any digital medium for any responsible purpose, subject to proper attribution of authorship. Given that the Canadian Medical Association holds copyright for all material published in $C M A J$ and charges fees for reprints and in some cases for other uses of $C M A J$ content, it is not in fact an open-access journal.

In comparison, Open Medicine does not assume the copyright of its authors' work. We believe that it is only fair and just that authors retain the ownership of their work; as such, Open Medicine does not charge reprint or other reproduction fees. We use a Creative Commons Copyright Licence (http://creativecommons.org/licenses /by-sa/2.5/ca) that also ensures derivative works are available through an open-access forum. It is through this creative and unlimited use of published material, with due attribution, that we believe scientific discourse can flourish. This truly open-access forum also has a contribution to make to a journal's integrity, independence and freedom. ${ }^{3}$ Proof of this potential to flourish lies with PLoS Medicine, an openaccess medical journal launched in 2004 that is now the fourth-leading medical journal in the world, with an impact factor of $\mathrm{I} 3.8$.

\section{Anita Palepu \\ Co-Editor, Open Medicine \\ For the Open Medicine Editorial Team}

Competing interests: None declared.

\section{REFERENCES}

I. Stanbrook MB, Flegel K, Sibbald B, et al. Congratulations to our colleagues at Open Medicine. CMAJ 2007;177:59-6r.

2. PubMed Central. Open access publishing. Bethesda (MD): National Institutes of Health; 2007. Available: www.pubmedcentral.nih.gov/about lopenaccess.html (accessed 2007 Aug I).

3. Willinsky J, Murray S, Kendall C, et al. Doing medical journals differently: Open Medicine, open access, and academic freedom. Can J Commun. In press. Available: http://pkp.sfu.ca/node/776 (accessed 2007 Aug I).

DOI:I0.I503/cmaj.I070092

\section{Correction}

In a commentary in the July $3 \mathrm{I}$ issue of $C M A J,{ }^{1}$ an error was made regarding the countries that have implemented needle-exchange programs. Scotland has not introduced such a program but has taken steps toward implementing one.

\section{REFERENCE}

I. Elliott R. Deadly disregard: government refusal to implement evidence-based measures to prevent HIV and hepatitis $\mathrm{C}$ virus infections in prisons. CMAJ 2007;177:262-4.

DOI:I0.1503/cmaj.07III6 